\title{
Appropriate Location and Deployment Method for Successful Iron Fertilization
}

\author{
Tai-Jin Kim \\ Department of Chemical Engineering, The University of Suwon, Hwasung, South Korea \\ Email: tjkim@suwon.ac.kr
}

How to cite this paper: Kim, T.-J. (2020) Appropriate Location and Deployment Method for Successful Iron Fertilization. Open Journal of Marine Science, 10, 149-172. https://doi.org/10.4236/ojms.2020.103012

Received: August 13, 2019

Accepted: June 14, 2020

Published: June 17, 2020

Copyright $\odot 2020$ by author(s) and Scientific Research Publishing Inc. This work is licensed under the Creative Commons Attribution International License (CC BY 4.0).

http://creativecommons.org/licenses/by/4.0/

\begin{abstract}
"High nutrient, low chlorophyll (HNLC)" regions were created by locking iron into sedimentary iron sulfides with hydrogen sulfide available from volcanic eruptions in surrounding oceans. Appropriate locations and deployment methods for the iron fertilization were far from volcanoes, earthquakes and boundaries of tectonic plates to reduce the chance of iron-locking by volcanic sulfur compounds. The appropriate locations for the large-scale iron fertilization are proposed as Shag Rocks in South Georgia and the Bransfield Strait in Drake Passage in the Southern Ocean due to their high momentum flux causing efficient iron deployment. The iron (Fe) replete compounds, consisting of natural clay, volcanic ash, agar, $\mathrm{N}_{2}$-fixing mucilaginous cyanobacteria, carbon black, biodegradable plastic foamed polylactic acid, fine wood chip, and iron-reducing marine bacterium, are deployed in the ocean to stay within a surface depth of $100 \mathrm{~m}$ for phytoplankton digestion. The deployment method of Fe-replete composite with a duration of at least several years for the successful iron fertilization, is configured to be on the streamline of the Antarctic Circumpolar Current (ACC). This will result in high momentum flux for its efficient dispersion on the ocean surface where diatom, copepods, krill and humpback whale stay together $(\sim 100 \mathrm{~m})$. Humpback whales are proposed as a biomarker for the successful iron fertilization in large-scale since humpback whales feed on krill, which in turn feed on cockpods and diatoms. The successful large-scale iron fertilization may be indicated by the return of the humpback whales if they could not be found for a long period before the iron fertilization. On-line monitoring for the successful iron fertilization focuses on the simultaneous changes of the following two groups; the increase concentration group (chlorophyll, $\mathrm{O}_{2}$, Dissolved Oxygen (DO), Di Methyl Sulfide (DMS)) and the decrease concentration group (nitrate, phosphate, silicate, $\mathrm{CO}_{2}$, Dissolved $\mathrm{CO}_{2}\left(\mathrm{DCO}_{2}\right)$ ). The monitoring of chlorophyll-a, nitrate phosphate, and silicate concentrations after deploying the Fe-replete complex is carried out throughout the day and night for the
\end{abstract}


accurate measurement of algal blooms.

\section{Keywords}

Appropriate Location, Deployment Method, Iron Fertilization, Volcanic Sulfur Compounds, Humpback Whale

\section{Introduction}

The sequestering atmospheric $\mathrm{CO}_{2}$ produced in enormous quantities by fossil fuel combustion, must be within the emission standards set up by the 2005 Kyoto Protocol and the 2016 Paris Agreement within the United Nations Framework Convention on Climate Change. It is well known that the increase of atmospheric $\mathrm{CO}_{2}$ causes the air temperature to rise, by contributing to climate change. It is evident that global $\mathrm{CO}_{2}$ emissions increase continuously over the years $\left(\mathrm{R}^{2}=\right.$ 0.9497), as shown in Figure 1.

Furthermore, fossil $\mathrm{CO}_{2}$ emissions $\left(\mathrm{Mt} \mathrm{CO}_{2} / \mathrm{yr}\right.$ ) were proportional to Total Deaths of the coronavirus outbreak with $\mathrm{R}^{2}=0.7081$ in Figure 2, as well described elsewhere [1].

It is therefore important to reduce the atmospheric $\mathrm{CO}_{2}$ not only for the global temperature decrease but also for the reduction of coronavirus casualties in 2020.

The iron fertilization was initiated by American oceanographer John Martin in 1988 [2]. Minas et al. [3] designated the terms of "high nutrient, low chlorophyll (HNLC)" in 1986. Martin's iron enrichment experiments [4] into the amounts of carbon drawn into the seas by algae formed the basis for 14 mesoscale international efforts during the last 25 years to understand the ocean's role in the Earth's carbon budget, as summarized in Table 1.

However, none has yet proposed economically feasible locations and deployment

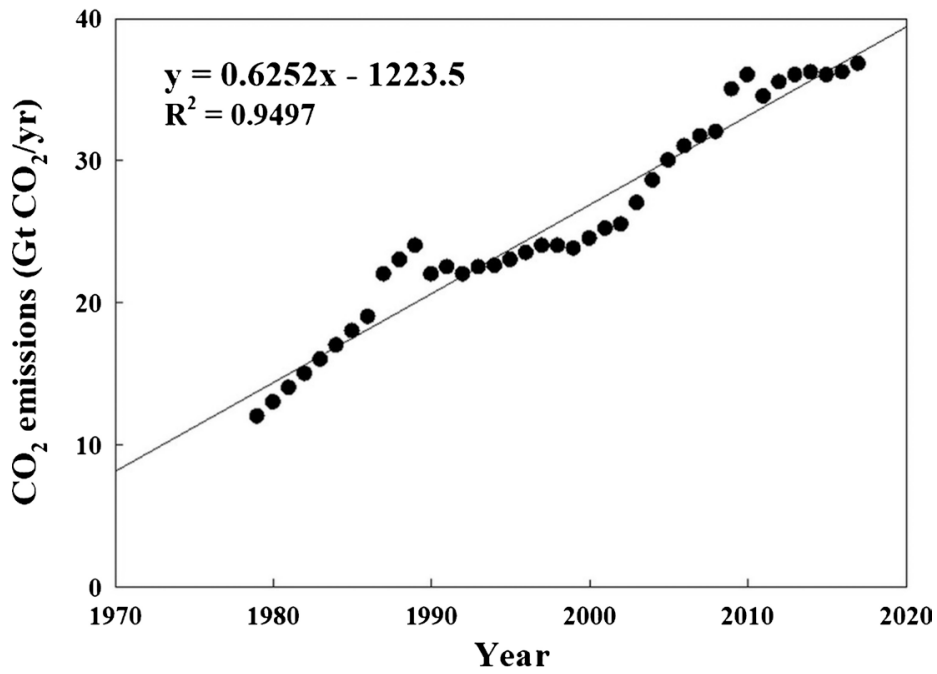

Figure 1. Yearly distribution of global $\mathrm{CO}_{2}$ emissions from 1979 to 2015. 


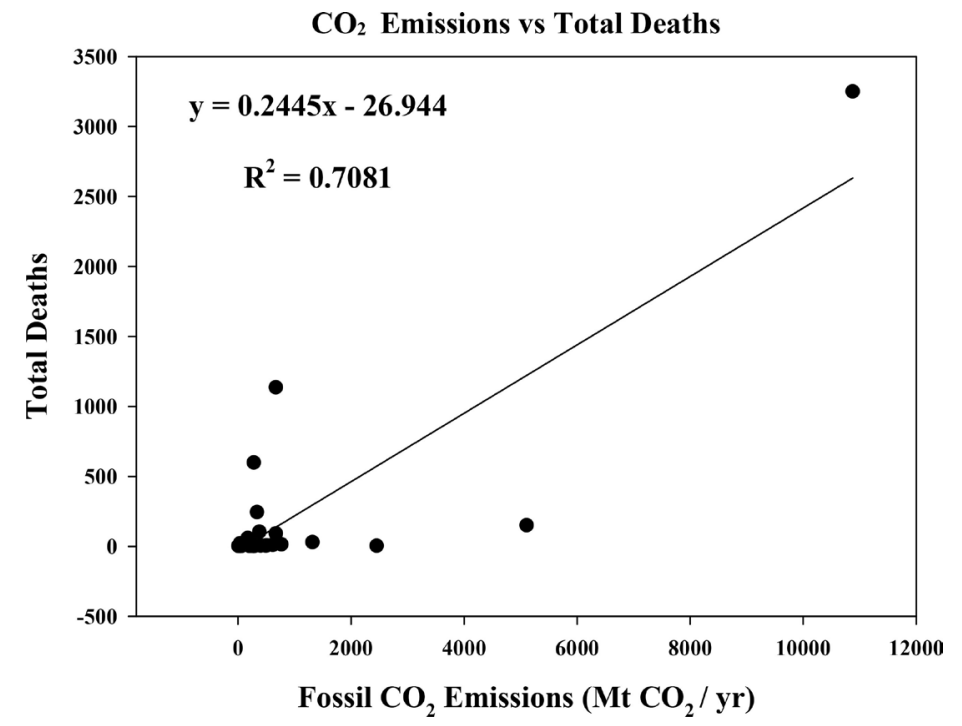

Figure 2. Total deaths by coronavirus cases were linearly correlated $\left(\mathrm{R}^{2}=0.7081\right)$ with global $\mathrm{CO}_{2}$ emissions in each country.

Table 1. Previous iron fertilizations with location, tectonic plate, and volcano [5].

\begin{tabular}{ccccc}
\hline Experiment & Date & Location & Tectonic Plate & Volcano (Number) \\
\hline IronEx I & October 1993 & $5^{\circ} \mathrm{S}, 90^{\circ} \mathrm{W}$ & Pacific/Nazca & Galapagos Islands (12) \\
IronEx II & June 1995 & $4^{\circ} \mathrm{S}, 107^{\circ} \mathrm{W}$ & Pacific/Nazca & near Seamount A at East Pacific Rise \\
SOIREE & February 1999 & $61^{\circ} \mathrm{S}, 140^{\circ} \mathrm{E}$ & Antarctic/Australian & Erebus (19) \\
EisenEx & November 2000 & $48^{\circ} \mathrm{S}, 21^{\circ} \mathrm{E}$ & Antarctic/African & Erebus (19)/near Marion at African Plate \\
SEEDS I & July 2001 & $48.5^{\circ} \mathrm{N}, 164.5^{\circ} \mathrm{E}$ & Pacific/Okhotsk & Kamchatka Peninsula (29) \\
SOFEX-N & January 2002 & $55^{\circ} \mathrm{S}, 172^{\circ} \mathrm{W}$ & Pacific/Antarctic & Erebus (19) \\
SOFEX-S & March 2002 & $66^{\circ} \mathrm{S}, 172^{\circ} \mathrm{W}$ & Pacific/Antarctic & Erebus (19) \\
SERIES & July 2002 & $51^{\circ} \mathrm{N}, 144.5^{\circ} \mathrm{W}$ & Pacific/North American & Augustine (15) \\
EIFEX & February 2004 & $50^{\circ} \mathrm{S}, 2^{\circ} \mathrm{E}$ & Antarctic/South American & Erebus (19)/near Bouvet at African Plate \\
SAGE & March 2004 & $46.5^{\circ} \mathrm{S}, 172.5^{\circ} \mathrm{E}$ & Pacific/Australian & Erebus (19)/near Chatham Islands with volcanic ash \\
from Taupo Volcanic Zone
\end{tabular}

methods. Therefore, further modification of such experimental protocols should be developed so that Martin's hypothesis is seen to be true on a large scale.

14 mesoscale iron enrichment experiments have been carried out in southern Africa, Australia, and New Zealand in the Southern Ocean with the Equatorial Pacific and the Subarctic Pacific [5]. As pointed out by Boyd in 2005 [6], the right location for the iron experiment is so important to be successful in the atmospheric $\mathrm{CO}_{2}$ sequestration. $\mathrm{SO}_{2}$ concentration in air over the Sierra Negra 
volcano in the Galapagos Islands during an eruption in October 2005 showed that $\mathrm{SO}_{2}$ plumes coincide with the surface nitrate, $\mathrm{DO}$ and $\mathrm{Fe}$-limited profiles in the Equatorial Pacific Ocean. It is thus evident that $\mathrm{SO}_{2}$ dispersion from sub-aerial volcanoes in tectonic plate boundaries, is linked to not only high nitrate concentration but also Fe-limitation, which are typical conditions in HNLC regions.

Sulfate reducing bacteria (SRB) produce $\mathrm{H}_{2} \mathrm{~S}$ from $\mathrm{SO}_{4}^{2-}$ while iron reducing bacteria produce $\mathrm{Fe}$ from $\mathrm{Fe}_{2} \mathrm{O}_{3} / \mathrm{FeOOH}$ [7]. The resultant submarine reaction produces iron sulfides $\left(\mathrm{FeS} / \mathrm{FeS}_{2}\right)$ that are buried in the submarine sediment as pyrite, which may be one of the reasons why 14 iron fertilization experiments of mesoscale enrichment, since IronEx I of 1993 till Haida Gwaii of 2012 in HNLC, have shown or a limited impact on the sequestration of atmospheric $\mathrm{CO}_{2}$. It is thus very important to choose the appropriate location and the deployment method of the iron fertilization. Martin's hypothesis of iron fertilization cannot practically be realized unless such an experiment is carried out at a specific location where serial volcanic eruptions have never occurred before at least recently to ensure a minimal presence of sulfur for lack of iron in the form of iron sulfides. The volcanic eruptions are important not only in relation to current eruptions but also to past eruptions in consideration of cumulative fallout of sulfur dioxide $\left(\mathrm{SO}_{2}\right)$-laden volcanic plumes.

The objective of the present study is to propose the appropriate location and the deployment method for successful iron fertilization in the oceans.

\section{Experiment}

\section{Bench Test of Hydrogen Sulfide with Iron}

Hydrogen sulfide $\left(\mathrm{H}_{2} \mathrm{~S}\right)$ is produced by 4 routes; volcanic gas $(0.04 \%-0.68 \%)$, sulfur oxidizing bacteria such as Beggiatoa, sulfate reducing bacteria (SRB) such as Desulfovibrio desulfuricans, and decomposed microorganism. Iron sulfate heptahydrate $\left(\mathrm{FeSO}_{4} \cdot 7 \mathrm{H}_{2} \mathrm{O}\right)$ has been widely used in the iron fertilization experiments as the main source of iron due to its high solubility in water. In the present study each of the 25 grams was dissolved in two bottles with 1 liter seawater; one was bubbled with pure $\mathrm{H}_{2} \mathrm{~S}$ gas (50 ppm, 2 liter per minute (LPM), 40 minutes) while another was kept as blank without $\mathrm{H}_{2} \mathrm{~S}$ bubbling. Figure 3(a) shows the orange color (left) for the control without $\mathrm{H}_{2} \mathrm{~S}$ bubbling while the dark black color (right) shows the experiment with $\mathrm{H}_{2} \mathrm{~S}$ bubbling.

Figure 3(b) indicates that air bubblings to the dissolved solution of $\mathrm{Fe}$ $\mathrm{SO}_{4} \cdot 7 \mathrm{H}_{2} \mathrm{O}$ did not any color change while pure $\mathrm{H}_{2} \mathrm{~S}$ bubblings gave the colors from pale blue to dark.

It was evident that $\mathrm{H}_{2} \mathrm{~S}$ gas from biogas induced rapid sedimentation of Chlorela vulgaris with clear supernatant in Figure $3(\mathrm{c})$. Such a clearness could be the result of loss of cell viability caused by either the lack of dissolved iron reacted with $\mathrm{H}_{2} \mathrm{~S}$ or the toxicity of $\mathrm{H}_{2} \mathrm{~S}$.

The sedimentary materials were filtered for analysis by X-ray diffractometer 


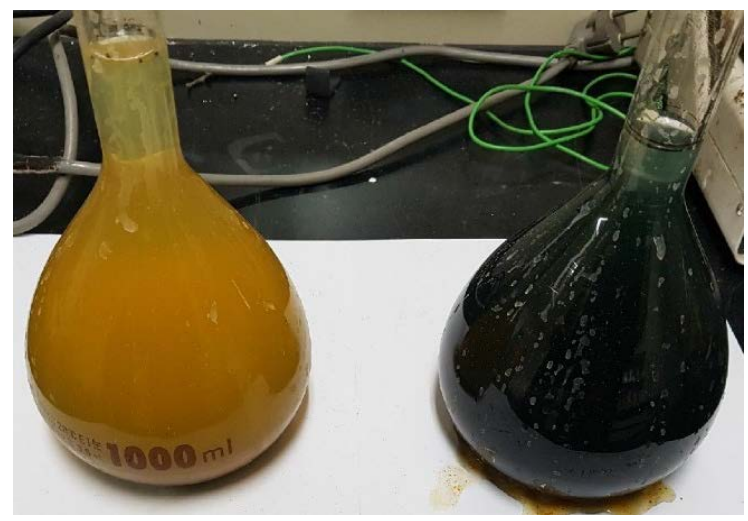

(a)

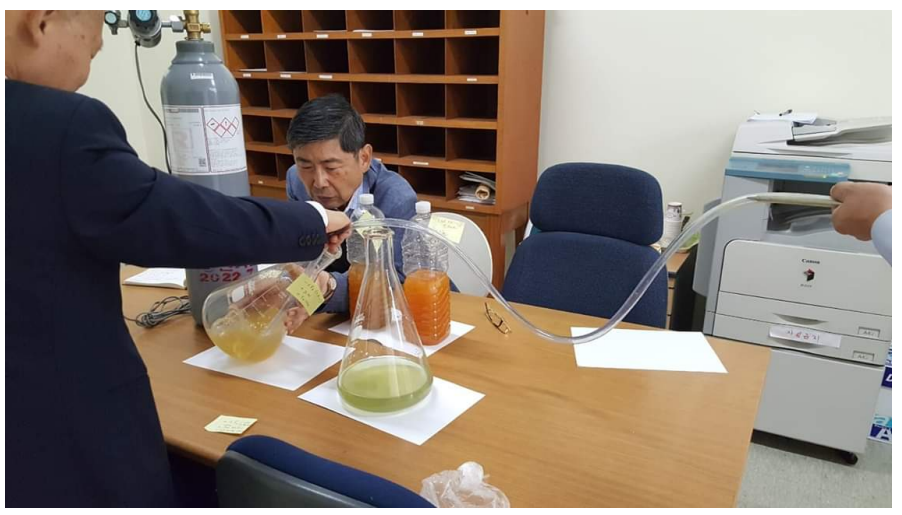

(b)

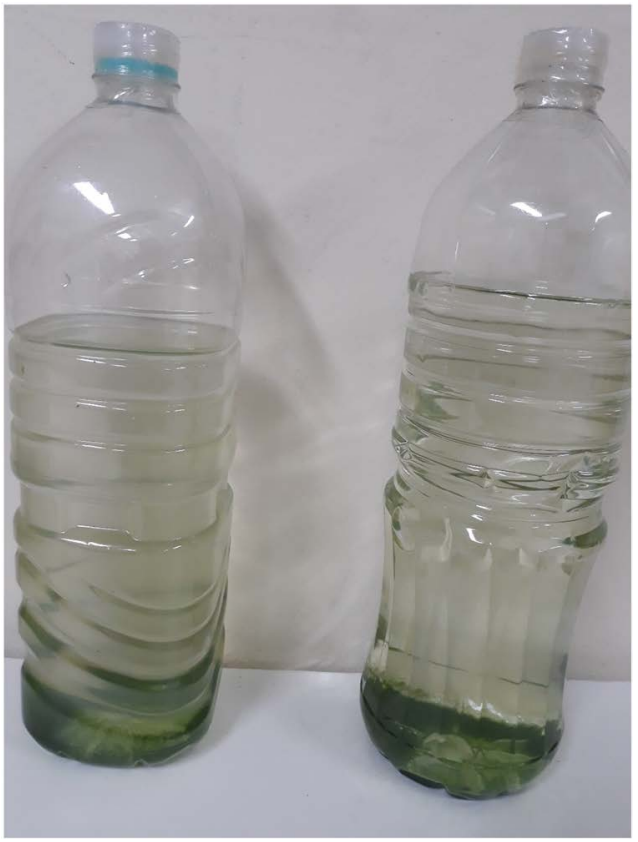

(c)

Figure 3. (a) Before (left) and after (right) pure $\mathrm{H}_{2} \mathrm{~S}$ gas bubbling (50 ppm, 2 LPM, 40 minutes) into 1 liter of seawater dissolved with 25 grams $\mathrm{FeSO}_{4} \cdot 7 \mathrm{H}_{2} \mathrm{O}$; b) Air (left) and $\mathrm{H}_{2} \mathrm{~S}$ (right) bubblings into 1 liter of seawater dissolved with 25 grams $\mathrm{FeSO}_{4} \cdot 7 \mathrm{H}_{2} \mathrm{O}$; (c) Before (left) and after (right) bubbling $\mathrm{H}_{2} \mathrm{~S}(500 \mathrm{ppm})$ from biogas into seawater (2 liter) with Chlorella vulgaris $\left(10^{7}\right.$ cells $\left./ \mathrm{ml}\right)$. 
(XRD) (Model Dmax2500/PC) to detect the presence of iron sulfides in the form of Greigite- $\mathrm{Fe}_{3} \mathrm{~S}_{4}$ among sulfur and iron oxide. Quantitative analysis implied that the crystallinity of $\mathrm{Fe}_{3} \mathrm{~S}_{4}$ constituted $4.06 \mathrm{wt} \%$ of total sedimentary materials among amorphous peaks. It was thus evident that $\mathrm{H}_{2} \mathrm{~S}$ binds Fe to sediment in black iron sulfide and deprives Fe of the growth of phytoplankton. For the appropriate iron fertilization, it was necessary to avoid locations with volcanoes to ensure least amount of sedimentary iron sulfide.

\section{Results and Discussion}

\subsection{Iron}

Iron is an important limiting nutrient for algae to produce chlorophyll and protein. Photosynthesis depends on adequate iron supply, whose concentration in water is quite low because of its low solubility. The primary producers in the ocean that absorb iron from aeolian dust, volcanic ash and upwelling [8] are typically phytoplankton or cyanobacteria, as shown in Figure 4.

Iron is then assimilated by consumers when they eat the bacteria or plankton,

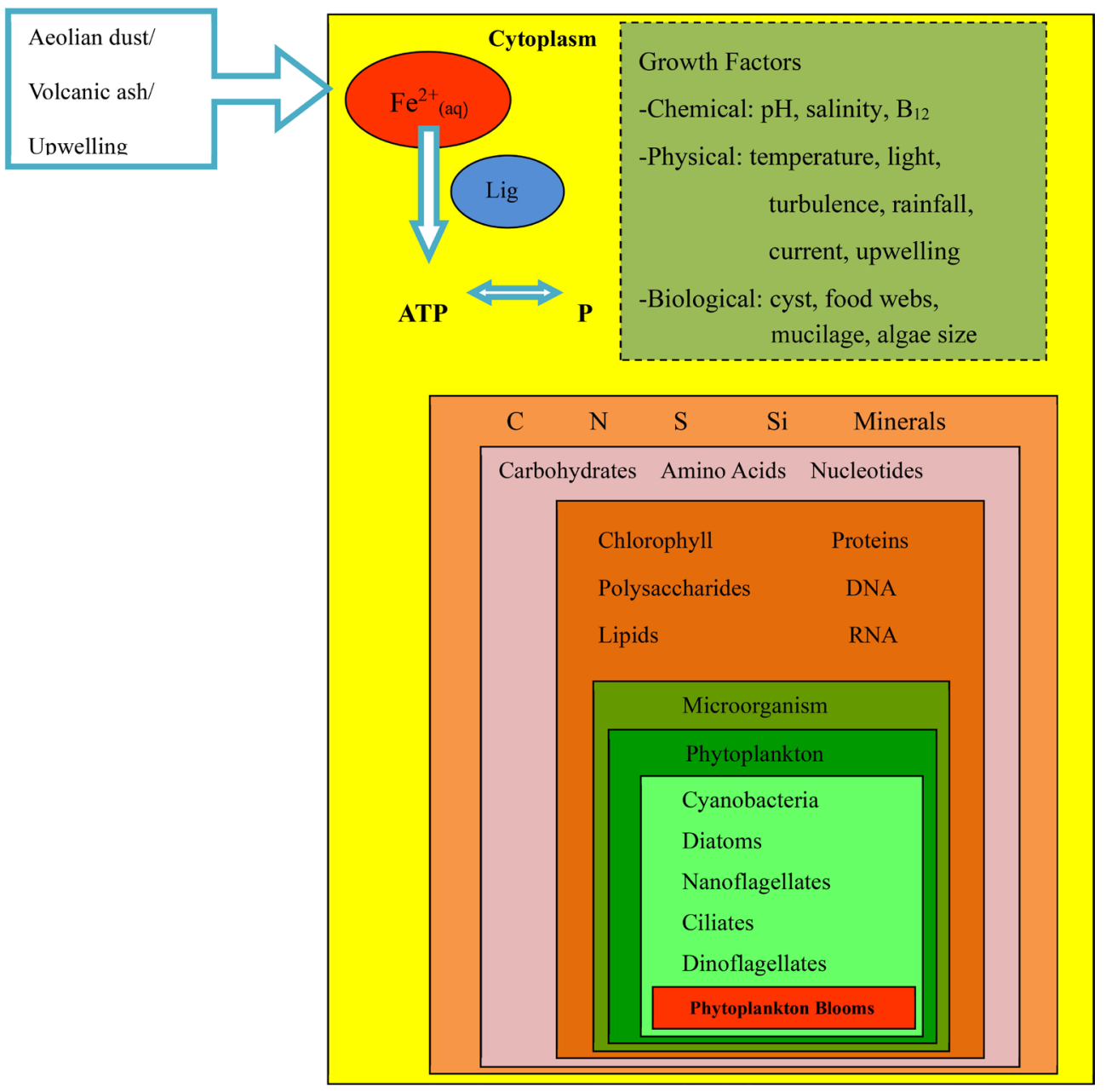

Figure 4. Conceptual hierarchy of photosynthetic iron initiation with light and phosphate for phytoplankton blooms under chemical, physical and biological growth factors. 
the latter providing a crucial source of food to many large aquatic organisms such as fish and whales. When animals, fish and plankton die, decomposing bacteria return iron to the soil and the water as part of the nutrient cycle on the Earth, as schematically shown in Figure 5.

Hematite $\left(\mathrm{Fe}_{2} \mathrm{O}_{3}\right)$ and goethite $(\mathrm{FeOOH})$ in the aeolian dust in Figure 5 tend to be associated with fine $(0.3-1 \mu \mathrm{m})$ particles, with long residence times (days) in the atmosphere and thus potentially long transport paths [9]. Under oxic conditions typifying surface waters, Fe exists largely in the oxidized ferric $\left(\mathrm{Fe}^{3+}\right)$ form as insoluble oxides, hydroxides and carbonates which readily precipitate and deposit in the sediments. Under anoxic conditions, Fe may be released from the sediments as more easily bindable $\mathrm{Fe}^{2+}$ prior to algal blooms. Since the solubility of $\mathrm{N}_{2}$ is very low in comparison with those of $\mathrm{CO}_{2}$ (high), $\mathrm{PO}_{4}^{3-}$ (moderate), and $\mathrm{SO}_{2}$ (very high), the overall algal growth rate is governed by the rate of $\mathrm{N}$ assimilation and $\mathrm{N}_{2}$ fixation, requiring plenty of iron atoms. In HNLC regions extremely low levels of dissolved iron (0.000004 ppm) [10] indicate low algal productivity. However, Synechococcus reached high densities in most HNLC regions. This may be caused by its ability to synthesize siderophores and iron-binding compounds, which facilitated the transport of iron ion into cells within 2 hours [11] during periods of iron deficiency. Iron is an enzyme cofactor in numerous biochemical pathways. Specifically, enzymes involved in photosynthesis, electron transport, energy transfer, $\mathrm{N}$ (specifically nitrate and nitrite) assimilation and (in the case of cyanobacteria) $\mathrm{N}_{2}$ fixation, require iron.

\subsection{Pathways of Iron and Sulfur}

Algae utilize the dissolved iron, $\mathrm{Fe}^{2+}{ }_{\text {(aq) }}$ while the amount of insoluble $\mathrm{FeS} / \mathrm{FeS}_{2}$ is

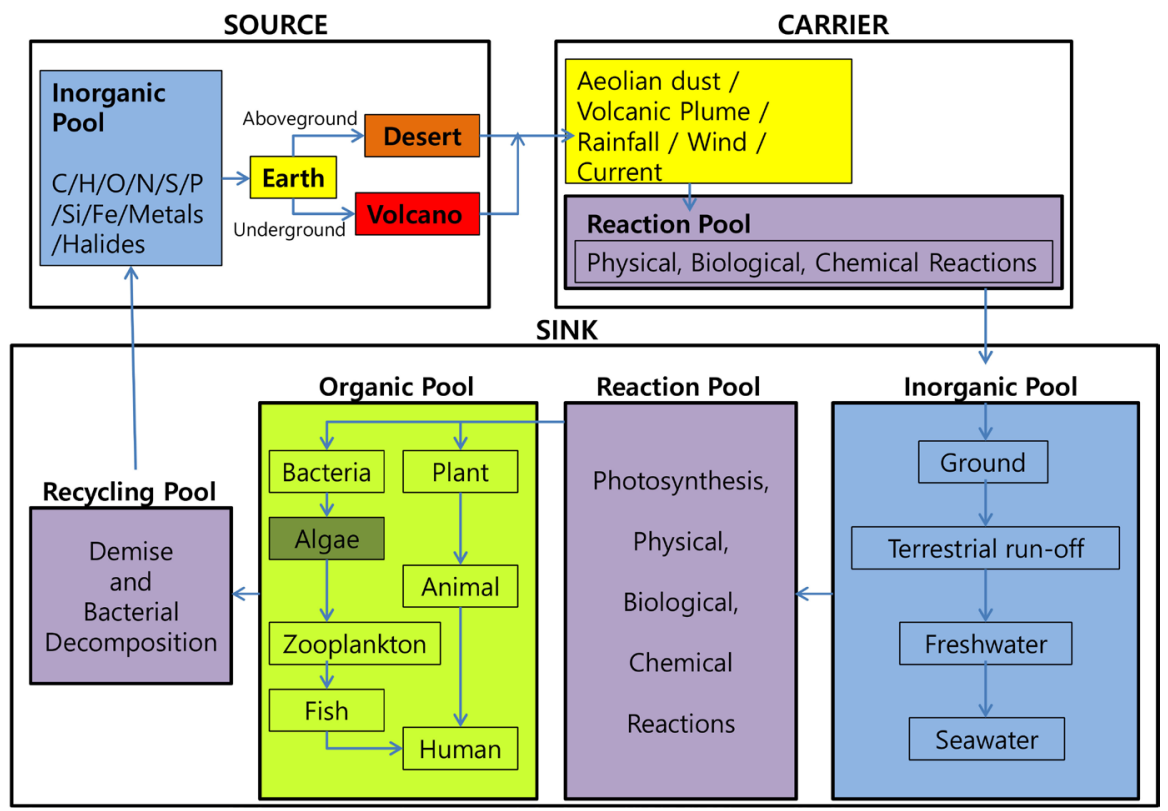

Figure 5. The source, carrier and sink for living organism with nutrient cycle on the Earth. 
significant if the volcanic activity is stronger due to the sulfur contribution, than the desert contribution of iron. Oceans are classified into four regions based on the amounts of nutrient and chlorophyll; HNLC (high-nutrient, low-chlorophyll), HNHC (high-nutrient, high-chlorophyll), LNLC (low-nutrient, low-chlorophyll) and LNHC (low-nutrient, high-chlorophyll), as investigated by Kim et al. [5].

Oceans with iron limitation can also be categorized in 4 regions depending upon the relative rates of accumulation of iron and sulfur, $\frac{(\mathrm{dS}-\mathrm{dFe})}{\mathrm{dt}}$, in the following order of largest to smallest: LNLC, HNLC, LNHC and HNHC, as summarized in Table 2.

Iron is available mainly from 3 sources-desert, volcano and upwelling while sulfur is available from 2 sources-volcano and desert, the latter being negligible due to its sulfur wash-out over a long time by rainfall and weathering. It is important to note that the Antarctic is not only has HNLC regions in the Southern Ocean but also has one of 8 major fishing areas of LNHC. This Antarctic duality can be caused by the co-presence of deserts Fe and volcanoes $\mathrm{S}$ in the Antarctic. The carriers of the inorganic nutrient pool in Figure 5 are winds and currents, which have seasonal variations. Therefore, 4 cases of HNLC, LNLC, HNHC, and LNHC can have their own variations with seasons.

In HNLC regions, a buffering capacity of $\mathrm{H}_{2} \mathrm{~S}$ is much larger than that of non-HNLC regions due to the additional supply of sulfur compounds from volcanic gas $\left(\mathrm{H}_{2} \mathrm{~S}, \mathrm{SO}_{2}, \mathrm{H}_{2} \mathrm{SO}_{4}\right)$ and volcanic ash (S, metallic sulfates). This leads to the more abundant product of $\mathrm{H}_{2} \mathrm{~S}$ not only from the volcanic gas but also from the enhanced sulfate reducing bacteria (SRB). Figure 6 shows the pathways of iron and sulfur prior to algae assimilation in both non-HNLC (broken line) and HNLC (solid line) regions. This indicates that the enhanced production of $\mathrm{H}_{2} \mathrm{~S}$ from volcanic eruptions in HNLC regions is changed from $\mathrm{Fe}^{2+}{ }_{\text {(aq) }}$ to $\mathrm{FeS}$ and $\mathrm{FeS}_{2}$ transformations. Therefore, both iron and sulfide may not easily penetrate into the overlying surface ocean but rather be pulled down into the hypoxic deep sediment $(\sim 1100 \mathrm{~m})$ with abundant $\mathrm{Fe}(\sim 565 \mu \mathrm{M})$ and $\mathrm{H}_{2} \mathrm{~S}(\sim 150 \mu \mathrm{M})$ in the

Table 2. Accumulation rates of iron and sulfur compounds for 4 cases of ocean regions.

\begin{tabular}{|c|c|c|c|c|c|c|}
\hline \multirow{2}{*}{\multicolumn{2}{|c|}{$\begin{array}{l}\text { Ocean } \\
\text { Regions }\end{array}$}} & \multicolumn{4}{|c|}{ Accumulation Rate } & \multirow{2}{*}{$\begin{array}{c}\text { Relative } \\
\text { Magnitude }\end{array}$} \\
\hline & & Iron & $(\mathrm{dFe} / \mathrm{dt})$ & Sulfur (dS/dt) & $\frac{(\mathrm{dS}-\mathrm{dFe})}{\mathrm{dt}}$ & \\
\hline \multirow{2}{*}{ LC } & LNLC & & - & ++ & ++ & $0>\frac{\mathrm{dFe}}{\mathrm{dt}} \ll \frac{\mathrm{dS}}{\mathrm{dt}} \gg 0$ \\
\hline & HNHC & & + & ++ & + & $0>\frac{\mathrm{dFe}}{\mathrm{dt}}<\frac{\mathrm{dS}}{\mathrm{dt}} \gg 0$ \\
\hline \multirow{2}{*}{$\mathrm{HC}$} & LNHC & & ++ & + & - & $0 \ll \frac{\mathrm{dFe}}{\mathrm{dt}}>\frac{\mathrm{dS}}{\mathrm{dt}}>0$ \\
\hline & $\mathrm{HNHC}$ & & ++ & - & -- & $0 \ll \frac{\mathrm{dFe}}{\mathrm{dt}} \gg \frac{\mathrm{dS}}{\mathrm{dt}}<0$ \\
\hline
\end{tabular}

(-; descending, --; significantly descending, +; ascending, ++; significantly ascending). 


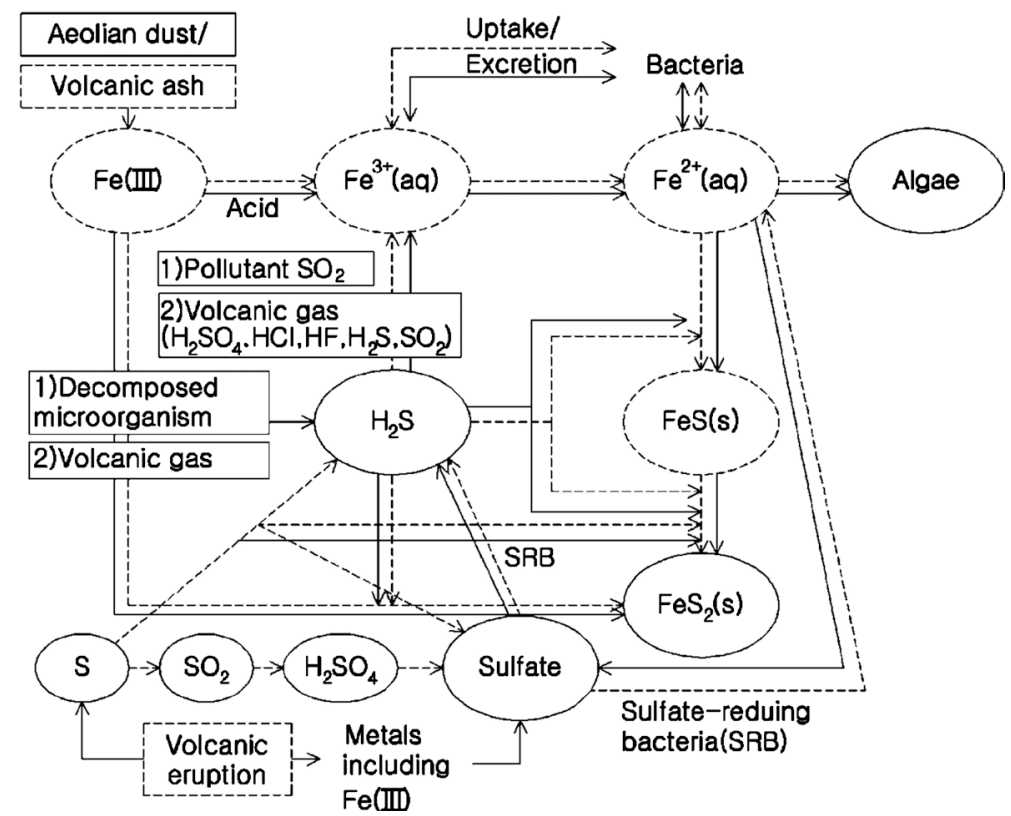

Figure 6. The pathways of iron and sulfur prior to algae assimilation in both non-HNLC (broken line) and HNLC (solid line) regions.

deep ocean of the Southern Ocean in the largest HNLC region, as observed by Aquilina et al. [12].

Iron in volcanic ashes have been reported in a number of complex forms that include $\mathrm{Fe}_{2} \mathrm{O}_{3}, \mathrm{Fe}_{3} \mathrm{O}_{4}, \mathrm{FeCl}_{2}, \mathrm{FeCl}_{3}, \mathrm{FeF}_{2}, \mathrm{FeF}_{3}, \mathrm{FeS}, \mathrm{FeS}_{2}, \mathrm{FeSO}_{4}$ and $\mathrm{Fe}_{2}\left(\mathrm{SO}_{4}\right)_{3}$ [13].

Sulfur emitted to the atmosphere is largely from human industrial activities such as burning fossil fuels $\left(50-100 \mathrm{Tg} \cdot \mathrm{S} \cdot \mathrm{yr}^{-1}\right)$, from the ocean via DMS (dimethylsulfide) emissions (16 Tg.S. $\left.\mathrm{yr}^{-1}\right)$, from subaerial volcanoes (10 $\left.\mathrm{Tg} \cdot \mathrm{S} \cdot \mathrm{yr}^{-1}\right)$, from aeolian dust in $\mathrm{CaSO}_{4} \cdot 2 \mathrm{H}_{2} \mathrm{O}\left(8 \mathrm{Tg} \cdot \mathrm{S} \cdot \mathrm{yr}^{-1}\right)$, from forest fire $\left(3 \mathrm{Tg} \cdot \mathrm{S} \cdot \mathrm{yr}^{-1}\right)$ and from coastal ocean and salt marches via COS (carbonyl sulfide) $\left(2.8 \mathrm{Tg} \cdot \mathrm{S} \cdot \mathrm{yr}^{-1}\right)$ [14]. Since most of HNLC regions are far from industrial complexes and residential areas, the contribution of fossil fuels and forest fires are negligible. The DMS and COS are internally recycled within the ocean and thus their contributions to the net sulfur cycle in HNLC regions is also largely negligible. The most significant external sources of sulfur compounds in HNLC regions are then the aeolian dust and the subaerial volcanoes. If iron $(\mathrm{Fe})$ in the volcanic ash reacts with dissolved sulfur (S) under steam heating $\left(\mathrm{T}>600^{\circ} \mathrm{C}\right.$ ) conditions [15], the product results in insoluble black ferrous sulfide (FeS), which reacts again with acidic hydrogen sulfide $\left(\mathrm{H}_{2} \mathrm{~S}\right)$ to form pyrite $\left(\mathrm{FeS}_{2}\right)$ and hydrogen $\left(\mathrm{H}_{2}\right)$ [16]. Volcanic gases are commonly composed in the order of $\mathrm{H}_{2} \mathrm{O}(37 \%-97 \%), \mathrm{CO}_{2}$, $\mathrm{SO}_{2}(0.50 \%-11.8 \%), \mathrm{H}_{2}, \mathrm{CO}, \mathrm{H}_{2} \mathrm{~S}(0.04 \%-0.68 \%), \mathrm{HCl}$ and $\mathrm{HF}$. For example, continuous volcanic eruptions at Mt. Erebus $(3794 \mathrm{~m})$ in Antarctica have resulted in excess sulfate $\left(\mathrm{SO}_{4}^{2-}\right)$ concentrations of $85.7 \mathrm{ppb}$ at Ross Ice Shelf [17].

Figure 6 shows that volcanic $\mathrm{S}$ compounds ( $\mathrm{S}, \mathrm{SO}_{2}, \mathrm{SO}_{3}, \mathrm{H}_{2} \mathrm{~S}, \mathrm{H}_{2} \mathrm{SO}_{4}$, sulfates) transform bio-available $\mathrm{Fe}^{2+}{ }_{\text {(aq) }}$ into rapid mackinawite $(\mathrm{FeS})$ and slow pyrite 
$\left(\mathrm{FeS}_{2}\right)$ sedimentations in HNLC regions [11] without releasing $\mathrm{Fe}^{2+}{ }_{(\mathrm{aq})}$ to phytoplankton during pyrite $\left(\mathrm{FeS}_{2}\right)$ formation. Therefore, HNLC regions, compared to non-HNLC and non-Fe limited regions [18], are big reservoirs of S compounds from extensive volcanic eruptions that induce sedimentary $\mathrm{FeS}$ and $\mathrm{FeS}_{2}$ in Fe-limited $\left(4 \times 10^{-6} \mathrm{ppm}\right)\left(0.07 \mathrm{nmol} \cdot \mathrm{L}^{-1}\right)$ oceans.

Soluble Fe sulfates are $\mathrm{FeSO}_{4},(\mathrm{Fe})_{2}\left(\mathrm{SO}_{4}\right)_{3},\left(\mathrm{NH}_{4}\right)_{2} \mathrm{Fe}\left(\mathrm{SO}_{4}\right)_{2}$ while insoluble Fe sulfides are $\mathrm{FeS}$ and $\mathrm{FeS}_{2}$. Soluble non-Fe sulfates are $\mathrm{Al}_{2}\left(\mathrm{SO}_{4}\right)_{3}, \mathrm{NH}_{4} \mathrm{HSO}_{4}$, $\left(\mathrm{NH}_{4}\right)_{2} \mathrm{SO}_{4},\left(\mathrm{NH}_{4}\right)_{2} \mathrm{SO}_{3}, \mathrm{BeSO}_{4}, \mathrm{CdSO}_{4}, \mathrm{CuSO}_{4}, \mathrm{MgSO}_{4}, \mathrm{MnSO}_{4}, \mathrm{NiSO}_{4}, \mathrm{KHSO}_{4}$, $\mathrm{Pb}_{2} \mathrm{SO}_{4}, \mathrm{Na}_{2} \mathrm{SO}_{4}$ and $\mathrm{NaS}_{2} \mathrm{O}_{3}$. Insoluble non-Fe sulfates are $\mathrm{Ag}_{2} \mathrm{SO}_{4}, \mathrm{BaSO}_{4}$, $\mathrm{PbSO}_{4}, \mathrm{Hg}_{2} \mathrm{SO}_{4}, \mathrm{RdSO}_{4}$ and $\mathrm{SrSO}_{4}$ while soluble sulfide is $\mathrm{H}_{2} \mathrm{~S}$ and insoluble sulfides are $\mathrm{CdS}, \mathrm{CuS}, \mathrm{PbS}$ and $\mathrm{PoS}$.

As seen in Figure $6, \mathrm{H}_{2} \mathrm{~S}$ is produced by 4 routes; 1 ) directly from volcanic gas with relatively high solubility $\left(0.3 \mathrm{~g} / 100 \mathrm{~g} \mathrm{H}_{2} \mathrm{O}\right)$ compared to that of FeS $(4.4 \times$ $\left.10^{-5}\right)$, 2) from sulfur by sulfur oxidizing bacteria such as Beggitoa, 3) from soluble sulfate by sulfate reducing bacteria (SRB) such as Desulfovibrio desulfuricans, 4) from soluble sulfides by hydrogenation. The more $\mathrm{H}_{2} \mathrm{~S}$ available from either the volcanic gas and sulfur oxidation, or soluble sulfates through SRB and soluble sulfides, the more sedimentation occurs in the forms of $\mathrm{FeS}$ and $\mathrm{FeS}_{2}$. Therefore, it is apparent that a volcanic eruption enhances the formation of FeS and $\mathrm{FeS}_{2}$, which allows less and less $\mathrm{Fe}$ to be available to algae causing iron limited conditions for "LC" (low-chlorophyll). On the other hand, nutrients such as nitrate, phosphate and silicate are fairly soluble and can be consumed to be utilized by algae. However, since Fe is limited, the growth of algae is retarded and thus nutrients are less utilized and further enriched, thereby becoming "HN" (high-nutrient).

SRB are widely distributed in deep water and sediments of lakes, rivers and oceans. With the capacity to use sulfate, thiosulfate or even elemental sulfur as electron receptors instead of oxygen in their respiratory chain, they aided in the recycling of elemental sulfur in nature. $\mathrm{SRB}$ produces $\mathrm{H}_{2} \mathrm{~S}$ from soluble $\mathrm{FeSO}_{4}$ or $\mathrm{Fe}_{2}\left(\mathrm{SO}_{4}\right)_{3}$, which is ultimately transformed to insoluble FeS and $\mathrm{FeS}_{2}$. Therefore, $\mathrm{H}_{2} \mathrm{~S}$ depletes $\mathrm{Fe}$ and lead to the Fe limited zone. In non-HNLC regions, not many sulfur compounds are present except those from algal or animal decomposition. In HNLC regions, however, many sulfur compounds are supplied from volcanoes. Thus, there was an abundant amount of $\mathrm{H}_{2} \mathrm{~S}$ pools as observed in the Southern Ocean. On the other hand, there are not many $\mathrm{H}_{2} \mathrm{~S}$ in non-HNLC due to a lack of external supply of sulfur compounds. Abundant quantities of SRB in the deep ocean $(\sim 1100 \mathrm{~m})$ of HNLC regions [12] might be the sign of the facilitated quantities of sedimentation of the Fe starved zone.

Most Fe supplied to HNLC regions, internally by algal and bacterial decompositions or externally by aeolian dust and volcanic ash, are eventually converted to insoluble $\mathrm{FeS}$ and $\mathrm{FeS}_{2}$ in the hypoxic deep ocean of HNLC regions unless assimilated to phytoplankton within the surface distance. In HNLC regions, Fe is supplied by either wind-driven upwelling (as is the case at the Gulf of Alaska in 
the Subarctic Pacific and at the Galapagos Islands in the Equatorial Pacific) or temperature-driven hydrothermal vents (as is in the Southern Ocean). Regardless of HNLC or non-HNLC regions, the additional driving force of $\mathrm{Fe}$ flux (Fe amount per unit area per unit time) is caused by the concentration gradient of dissolved Fe. This occurs between the hypoxic deep ocean, with plenty of decomposed $\mathrm{Fe}$, as the source of Fe and the oxic surface ocean with Fe-starved algae as a sink of Fe. In HNLC, however, the amount of Fe available to algae was far less $(0.000004 \mathrm{ppm})$ than that in non-HNLC regions $(0.0034 \mathrm{ppm})$ due to greater sedimentations of $\mathrm{FeS}$ and $\mathrm{FeS}_{2}$ by the abundant supply of sulfur compounds from the volcanic eruptions in HNLC regions. This is compared to the minor supply of sulfur from the desert dust. In Table 3, flux and gradient with source and sink in HNLC regions were summarized, which implied that momentum (current flow rate), heat (temperature) and mass (Dissolved Oxygen, $\mathrm{Fe}^{2+}{ }_{(\mathrm{aq})}$, FeS, $\mathrm{H}_{2} \mathrm{~S}$, Algae, Sulfate Reducing Bacteria) fluxes between the surface and deep oceans could occur in HNLC regions.

The low dissolved nutrients are supplied by deep-sea hydrothermal vents driven by the temperature gradient between the cold deep ocean and the warm surface ocean including molecular diffusion along the concentration gradient.

The yearly continuous volcanic eruptions at Mt. Erebus, allow a lot of sulfur compounds with fast dissipation into the deep ocean. This is associated with the highest nutrients (N, P, Si) among global HNLC regions becoming "high nutrients $(\mathrm{HN})$ " while $\mathrm{Fe}$ is mainly sedimented in $\mathrm{FeS}$ and $\mathrm{FeS}_{2}$ by enriched pools of $\mathrm{H}_{2} \mathrm{~S}$ and SRB leading to Fe-limited or "low chlorophyll (LC)".

The hypoxic condition in the deep ocean allowed SRB (Desulfovibrio 40 $\mu \mathrm{m}$ ), surviving only one day in air, to produce $\mathrm{H}_{2} \mathrm{~S}$ and $\mathrm{Fe}^{2+}$, the latter being partly engulfed by bacteria for their own concentrated growth $\left(10^{8}-10^{9}\right.$ cells $\left.\cdot \mathrm{mL}^{-1}\right)$. SRB produced $\mathrm{H}_{2} \mathrm{~S}$ and metal ions along with $\mathrm{Fe}^{2+}$ from high sulfates in the hypoxic water, while HNLC regions in extensive volcanic eruptions were enriched with sulfur compounds $\left(\mathrm{S}, \mathrm{H}_{2} \mathrm{~S}, \mathrm{SO}_{2}, \mathrm{H}_{2} \mathrm{SO}_{4}\right.$ and sulfates) and $\mathrm{FeSO}_{4}$ to produce more $\mathrm{H}_{2} \mathrm{~S}$ and $\mathrm{Fe}^{2+}$. Consequently, $\mathrm{H}_{2} \mathrm{~S}$ might lock and hold more $\mathrm{Fe}^{2+}$ in the forms of $\mathrm{FeS}$ and $\mathrm{FeS}_{2}$ making less $\mathrm{Fe}^{2+}$ accessible to algae in the surface ocean. Importantly, the bacterial growth in the hypoxic water was further enhanced by the plentiful supply of $\mathrm{Fe}^{2+}$ from iron sulfate through their own sulfate-reducing

Table 3. Momentum, heat and mass fluxes between source $(+)$ and sink $(-)$ in the surface and deep oceans in HNLC regions.

\begin{tabular}{|c|c|c|c|c|c|c|c|c|}
\hline Flux & Momentum & Heat & & & Mas & & & \\
\hline Gradient & $\begin{array}{c}\text { Current } \\
\text { Flow Rate }(v)\end{array}$ & $\begin{array}{c}\text { Temperature } \\
\text { (T) }\end{array}$ & $\begin{array}{c}\text { Dissolved Oxygen } \\
\text { (DO) }\end{array}$ & $\mathrm{Fe}^{2+}{ }_{(\mathrm{aq})}$ & $\mathrm{FeS}$ & $\mathrm{H}_{2} \mathrm{~S}$ & Algae & $\begin{array}{c}\text { Sulfate Reducing } \\
\text { Bacteria (SRB) }\end{array}$ \\
\hline $\begin{array}{l}\text { Surface } \\
\text { Ocean }\end{array}$ & + & + & + & - & - & - & + & $\begin{array}{l}\text { 1) } \\
-\end{array}$ \\
\hline $\begin{array}{c}\text { Deep } \\
\text { Ocean }\end{array}$ & - & - & - & + & + & + & $\begin{array}{l}3) \\
-\end{array}$ & $\begin{array}{l}\text { 2) } \\
+\end{array}$ \\
\hline
\end{tabular}

Note; 1) SRB survives only one day under air exposure. 2) $10^{8}-10^{9}$ cells $\cdot \mathrm{mL}^{-1}$. 3) dead or sinking algae. 
activity. The more sulfate is available from volcanic eruptions, the more $\mathrm{H}_{2} \mathrm{~S}$ is produced in HNLC regions to lock more $\mathrm{Fe}^{2+}$ to the sediment in $\mathrm{FeS}$ and $\mathrm{FeS}_{2}$. Therefore, HNLC regions are Fe-limited due to the relatively abundant supply of sulfur compounds from the extensive volcanic eruptions. This is especially the case in the Southern Ocean with the fastest ( $\sim \mathrm{km}$ per hour) and the largest volumetric flow rate $\left(1.47 \times 10^{8} \mathrm{~m}^{3}\right.$ per second around Tasmania) of the ACC. The yearly continuous volcanic eruptions at Mt. Erebus transfer a lot of sulfur compounds with fast dissipation into the deep ocean. This leaves the highest nutrients $(\mathrm{N}, \mathrm{P}, \mathrm{Si})$ among global HNLC regions while $\mathrm{Fe}$ is mainly sedimented in $\mathrm{FeS}$ and $\mathrm{FeS}_{2}$ by enriched pools of $\mathrm{H}_{2} \mathrm{~S}$ and SRB leading to Fe-limited "lowest chlorophyll".

Simultaneous locking of Fe and S, in the form of insoluble black FeS $(4.4 \times$ $10^{-5} \mathrm{~g} / 100 \mathrm{~g} \mathrm{H}_{2} \mathrm{O}$ ) and pyrite $\left(\mathrm{FeS}_{2}\right)$, can be thus enhanced by the abundant supply of sulfur compounds during or after the volcanic eruptions in HNLC regions. In other words, volcanic sulfur compounds pull iron down toward $\mathrm{FeS} / \mathrm{FeS}_{2}$ sedimentation. Thus there is no key to unlock the sedimentary pyrite $\left(\mathrm{FeS}_{2}\right)$ formation except the iron- and sulfur-oxidizing bacteria such as Acidithiobacillus ferrooxidans, Alicyclobacillus and Sulfobacillus. These bacteria live in pyrite deposits to metabolize ferrous iron and sulfur and produce sulfuric acid, with optimal pH (1.3 - 4.5), far acidic than that of ocean (7.8 - 8.4). Such an exceptional pyrite oxidation has been observed at the marine shore sulfidic mine in northern Chile with extreme acidity $(1-4)$ and high salinity $(10-20 \mathrm{~cm}$ thick salts) [21]. Therefore, HNLC regions have a stronger lock of sulfur compounds, without the key of iron sulfides, than that of non-HNLC regions. This leads to the present iron limited and resultantly "low chlorophyll (LC)" waters while nitrate, phosphate and silicate, incorporated into the organic material through photosynthesis, are released in the ocean during bacterial respiration, accumulating in the form of "high nutrient (HN)" in HNLC regions.

\subsection{HNLC Regions}

In most regions of the world ocean photosynthetic production is limited by the availability of the nutrients of nitrate and phosphates. Regions where nutrient concentrations are high, are usually characterized by high concentrations of chlorophyll in surface waters. There are, however, large areas of the world's oceans $(>30 \%)$ where the concentrations of nutrients are high yet chlorophyll is low (HNLC). Martin and Fitzwater [2] hypothesized that primary productivity in HNLC regions was limited by the availability of iron while HNLC regions consist of the Subarctic Pacific, Equatorial Pacific and Southern Ocean, as illustrated in Table 4.

Most nitrates are highly soluble $\left(\mathrm{NH}_{3} 1776 \mathrm{~g} / 100 \mathrm{~g}\right.$ water, $\left(\mathrm{NH}_{4}\right)_{2} \mathrm{HPO}_{4} 42.9$, $\mathrm{NH}_{4} \mathrm{HSO}_{4}$ 100, $\mathrm{NH}_{4} \mathrm{NO}_{3}$ 118, $\left(\mathrm{NH}_{4}\right)_{2} \mathrm{SO}_{4}$ 70.6, $\left(\mathrm{NH}_{4}\right)_{2} \mathrm{SO}_{3}$ 47.9). Phosphate $\left\{(\mathrm{FeOOH})_{\mathrm{N}} \equiv \mathrm{PO}_{4}^{3-}, \mathrm{FePO}_{4} \cdot 4 \mathrm{H}_{2} \mathrm{O}, \mathrm{Fe}_{3}\left(\mathrm{PO}_{4}\right)_{2} \cdot \mathrm{nH}_{2} \mathrm{O}\right\}$ are also soluble in water especially at a $\mathrm{pH}$ of above 8.2 , as is in oceans. The solubility of amorphous silica 
Table 4. Distribution of nutrients (nitrate, phosphate and silicate), chlorophyll and aeolian dust in HNLC regions.

\begin{tabular}{cccccc}
\hline HNLC & $\begin{array}{c}\text { Nitrate } \\
(\mu \mathrm{M})\end{array}$ & $\begin{array}{c}\text { Phosphate } \\
(\mu \mathrm{M})\end{array}$ & $\begin{array}{c}\text { Silicate } \\
(\mu \mathrm{M})\end{array}$ & $\begin{array}{c}\text { Chlorophyll-a } \\
\left(\mu \mathrm{g} \cdot \mathrm{l}^{-1}\right)\end{array}$ & $\begin{array}{c}\text { Aeolian dust } \\
{[19]}\end{array}$ \\
\hline Souther $\left.\mathrm{m}^{-2} \cdot \mathrm{yr}^{-1}\right)$ \\
\hline Equatorial Pacific [20] & 31 & 3.4 & 32 & 2.2 & 4 \\
Subarctic Pacific [19] & 7 & 1.0 & 3 & 0.3 & 7 \\
\hline
\end{tabular}

in water at $25^{\circ} \mathrm{C}$ is $0.01 \%$ to $0.012 \%$. Due to the abundance of silicate (45- 75 $\mathrm{wt} \%)$ in trace metals [21] from volanic eruptions, the resultant concentration of silicate in HNLC is relatively high, as typically summarized in Table 4.

Diatoms and copepods have Sverdrop critical depths of about $100 \mathrm{~m}$. Copepod numbers are controlled by a combination of competition and predation by krill [22]. Humpback whales reside in the top $100 \mathrm{~m}$ layer to feed on krill which are also mainly in the top $100 \mathrm{~m}$ layer. Therefore, the depth for the iron fertilization can be in the top $100 \mathrm{~m}$ where diatoms, krill, and humpback reside together while copepods live deeper to escape from krill with an inverse relationship between krill and copepod abundances [22]. Although diatoms are intermediates in the food webs cycle followed by copepods, krill or even humpback whales, diatoms feed on photosynthetic cyanobacterium picoplankton and reproduce cell walls. They use a cheap (8\%) energy requirement with a genetically adapted system in iron-limited HNLC regions. The successful blooms by diatoms through the iron fertilization are inevitable not only to draw-down the atmospheric $\mathrm{CO}_{2}$ through their high sinking rate $\left(0.96 \mathrm{~m} \cdot \mathrm{d}^{-1}\right)$ but also to be fundamentally abundant prey for copepods, krill and, sequentially fish and humpback whale.

$\mathrm{SO}_{2}$ concentration in air over the Sierra Negra volcano in the Galapagos Islands during an eruption in October 2005 showed that $\mathrm{SO}_{2}$ plume coincides with the surface nitrate, DO and Fe-limited profiles in the Equatorial Pacific Ocean. It is thus evident that $\mathrm{SO}_{2}$ dispersion from sub-aerial volcanoes in tectonic plate boundaries, is linked to not only high nitrate concentration but also Fe-limitation, which are typical conditions of HNLC regions.

Sulfate reducing bacteria (SRB) produce $\mathrm{H}_{2} \mathrm{~S}$ from $\mathrm{SO}_{4}^{2-}$ while iron reducing bacteria produce $\mathrm{Fe}$ from $\mathrm{Fe}_{2} \mathrm{O}_{3} / \mathrm{FeOOH}$ [7]. The resultant submarine reaction produces iron sulfides $\left(\mathrm{FeS} / \mathrm{FeS}_{2}\right)$ that are buried in the submarine sediment as pyrite, which may be one of the reasons why 14 iron fertilization experiments of mesoscale enrichment, from IronEx I in 1993 till Haida Gwaii in 2012 in HNLC, have shown limited impact on the sequestration of atmospheric $\mathrm{CO}_{2}$. It is thus very important to choose the appropriate location of the iron fertilization. Martin's hypothesis of iron fertilization cannot practically be realized unless such an experiment is carried out at the specific location where serial volcanic eruptions have never occurred before to ensure a low quantity of sulfur compounds causing a lack of iron in the form of iron sulfides. The volcanic eruptions are important not only in relation to current eruptions but also to past eruptions when 
considering of cumulative fallout of sulfur dioxide $\left(\mathrm{SO}_{2}\right)$-laden volcanic plumes.

The Southern Ocean is dually shielded by the Antarctic and isolated from the Continents by the East Wind Drift $\left(60^{\circ} \mathrm{S}\right)$ and the West Wind Drift or the ACC $\left(40^{\circ} \mathrm{S}-60^{\circ} \mathrm{S}\right)$. The ACC carries rich nutrients from submarine volcanoes in the Southern Ocean, and from the constant yearly volcanic eruptions of Mt. Erbus $(3794 \mathrm{~m})$. These nutrients become wide-spread and circle around the Antarctic, which acts as a Continuous Stirred Tank Reactor (CSTR). The high revolution ( $\sim 4 \mathrm{~km}$ per hour) agitator of the ACC is the largest current in the world (flow rate is $1.3 \times 10^{8} \mathrm{~m}^{3} / \mathrm{sec}$ ) and is driven by the temperature gradient between the Arctic and the Antarctic along with strong Westerly Winds and the Southern Jet Stream.

Diatom blooms play a central role in supporting food webs and sequestering biogenic carbon to depth. A diatom spring bloom in offshore New Zealand waters was likely terminated by iron limitation even though diatoms consumed < $1 / 3$ of dissolved iron. Thus, bloom duration and magnitude were primarily set by competition for dissolved iron between microbes and small phytoplankton versus diatoms [23].

\subsection{Appropriate Location for Iron Fertilization}

The location of the appropriate iron fertilization can be preferred to the junction between ACC and the down region of the deep-sea hydrothermal vents in a submarine volcano. However, it may apply to all locations throughout the Antarctic because the ACC is circulating clockwise around the Antarctic with high flow velocity to form a kind of continuous stirred tank reactor (CSTR). This means that the concentrations of nutrients are well mixed to be uniform regardless of the location, as long as they are located within the Antarctic under the streamline of the ACC. Although 14 iron fertilization experiments during the last 25 years have been conducted including LOHAFEX in 2009 [24] and Haida in 2012, such experiments have never been conducted at a location that is free from serial volcanic eruptions for the removal of volcanogenic sulfur. It is recommended that the appropriate iron fertilization experiment be conducted far from sulfur sources such as volcanoes and boundaries of tectonic plates, not only to minimize the iron consumption by the chemical formation of sedimentary $\mathrm{FeS}$ and $\mathrm{FeS}_{2}$ due to the volcanic $\mathrm{S}$ compounds, but also to maximize the availability of dissolved Fe to phytoplankton. The dissolved Fe is engulfed by cyanobacteria (the diazotrophs Trichidesmium and Crocosphaera Watsonii, and the non-diazotrophs Synechococcus and Prochlorococcus) to be grazed on by diatoms and subsequently by copepods, krill, small fish, penguin and humpback whale.

Hook Ridge in the Central Basin of the Bransfield Strait of the Southern Ocean and Shag Rocks $(200 \times 50 \mathrm{~km})$ in South Georgia in northern Scotia Sea are suggested as the appropriate location for the large-scale iron enrichment experiment due to the following reasons, 
1) Volcanic aspects to avoid the sulfur compounds.

- Not over the boundaries of the Earth plate (for Hook Ridge), but just outside of the Northern Scotia plate (for Shag Rocks)

- Far from active volcanoes and earthquakes (for Shag Rocks)

- Low concentrations of sulfur compounds $\left(\mathrm{S}^{0}, \mathrm{SO}_{3}^{2-} \mathrm{SO}_{4}^{2-}, \mathrm{H}_{2} \mathrm{~S}, \mathrm{SO}_{2}\right)$ to minimize iron sulfide formation.

2) Iron input as much as possible for algal blooms.

- Downwind region of the Patagonian and Chile deserts for aeolian supply of minerals with iron (for Shag Rocks)

- Near to rocky islands covered partly with ice for self aeolian dust flux input and nutrient enriched ice melt (for Shag Rocks)

- Wind-driven upwelling, density-driven vortex mixing, and previous volcanic eruptions with an abundant quantity of iron sediments due to submarine volcanic eruptions forming a pool of dissolved iron in the pore deep ocean (for Hook Ridge)

- Not bulk scale additions of direct iron or iron sulfate, but deploying natural clays or soils available on nearby islands with a possible iron content in the range of $3.5 \mathrm{wt} \%$ to $6 \mathrm{wt} \%$, as observed elsewhere in the Continents, along with volcanic ash desulfurized by rainfall and weathering for long time.

3) High momentum flux for fast dispersion around the experimental zone.

- Cold and fast Weddell Sea Deep Water passes through to meet the warm waters of the Subarctic, creating a zone of upwelling nutrients (for Shag Rocks)

- Located in-between South America and the Antarctic with the narrow Drake Passage providing the ACC with high linear flow velocity ( $4 \mathrm{~km}$ per hour, $V$ ) and the largest ocean current $\left(1.25 \times 10^{5} \mathrm{~m}^{3}\right.$ per second $)$ for fast deployment of the Fe-replete complex $\left(\mathrm{m}_{\mathrm{A}}\right)$ over a wide oceanic surface area with a high momentum flux $\left(\mathrm{m}_{\mathrm{A}} \cdot \mathrm{V}\right)$ in large scale iron fertilization (for Hook Ridge).

4) Nutrients for effective algal bloom to be near "high chlorophyll (HC)".

- Region where cyanobacterium Synechoccus live as initial efficient consumer of iron

- Abundant coccolithophorids and silicoflagellates are dominated in the Weddell Sea, which passes through (for Shag Rocks)

- High concentration of silica or silicic acid for proper growth of diatoms such as Corethron criophilum, Chaetoceros neglectus, Chaetoceros dichaeta [25], which are invulnerable to predation by zooplankton and sink rapidly $(0.96 \mathrm{~m}$ $\mathrm{d}^{-1}$ ) upon death for efficient sequestration of atmospheric $\mathrm{CO}_{2}$

- A place where the Antarctic krill and humpback whale are currently present with stable food webs ecosystem.

5) Environmental aspects to increase the probability of a successful iron enrichment experiment.

- Not far from sources of search and rescue

- Experimental period can be the duration between November and April or preferably January for high irradiance and warm water temperature with a large quantity of melting ice for phytoplankton bloom. 
The dissolved iron is engulfed by picoplankton and grazed on by diatoms and subsequently by copepods, krill, small fish and finally whales. Humpback whales have a worldwide population of about 80,000 which feed on krill, copepods and small fish. Humpback whales have been observed not only in 3 HNLC regions of the Subarctic Pacific (Alaska), the Equatorial Pacific (Galapagos) and the Southern Ocean (Drake Passage, South Georgia), Antarctic Peninsula (south of Cape Horn) but also in another 4 locations; Iceland (Snaefellsnes peninsula), Japan (Zamami), Guam, and Hawaii (Maui). It can be thus postulated that humpback whales are a good biomarker for the location of the appropriate iron enrichment experiment. In other words, it is preferable that such an iron experiment be carried out somewhere humpback whales feed and breed, since the fertilized iron can be fed on by the phytoplankton and consumed by copepod and krill, and eventually by humpback whales. July is usually the mating season for the Southern Hemisphere humpback whales, with births occurring in June of the subsequent year. A calf is generally strong enough to migrate with its mother at three months old. Since humpback whales feed on krill and small fish in the Antarctic during the winter while they breed at the tropical or subtropical oceans during the summer, it is recommended that the iron fertilization experiment start during the early summer of January when there is a warm coastal temperature $\left(-3^{\circ} \mathrm{C}-15^{\circ} \mathrm{C}\right)$ and sufficient irradiance. When humpbacks return to the Southern Ocean after a long journey from the Northern Hemisphere tropical or subtropical oceans, the iron stimulated area, somewhere in the Southern Ocean, may have already algal bloomed with a friendly eco-system community of heterotropic bacteria, picoeukaryotes and picoplankton, diatoms, copepods and krill if the intended iron enrichment experiment is successful on a large scale.

\subsection{Deployment Method for Iron Fertilization}

As reviewed by Shaked and Lis [26], small phytoplanktons are favored under Fe limitation. On the basis of relative scale of Fe availability established from phytoplankton uptake rates, picoplankton such as Synechococcus and Synechocystis appear to be grazed by diatoms such as Thalassiosira spp. and Chaetoceros spp., flagellates of Phaecysts spp. and dinoflagellates of Chrysochromulina Ericina. Such results correlate with other results for four size classes $(0.2-2,2-5,5-20$, and $>20 \mu \mathrm{m}$ ) of $\mathrm{Fe}$ cycle with the highest Fe uptake rate of picoplankton. It was suggested that copepod numbers can be controlled by a combination of competition and predation by krill, the latter being fed on by humpback whale. It can be thus postulated that the route of Fe availability starts from picoplankton, diatoms, copepods and krill to the final destination of humpback whale. Therefore, in order to make successful algal blooms for feasible atmospheric $\mathrm{CO}_{2}$ sequestration, the size of Fe source must be smaller than that of picoplankton $(<2 \mu \mathrm{m})$.

Fe-replete compounds are deployed to stay as long as possible within the 100 $\mathrm{m}$ deep surface area of the ocean with aid of Fe-replete eco-friendly composite consisting of natural aeolian dust and/or clay, volcanic ash, mucilaginous cya- 
nobacteria to avoid the chemical conversion of iron to iron sulfide and enhance phytoplankton digestion. Iron input for algal blooms is not provided by bulk scale additions of direct iron or iron sulfate, but by instead deploying natural clays or soils available around nearby islands with a possible content of iron in the range of $3.5 \mathrm{wt} \%$ to $6 \mathrm{wt} \%$, as observed elsewhere in the Continents [8], along with volcanic ash desulfurized by rainfall and weathering for long time. Such a Fe-replete complex is encapsulated by agar so that phytoplankton can digest easily and slowly prior to its sinking to the deep ocean where iron is changed to iron sulfide $(\mathrm{FeS})$ and eventually pyrites $\left(\mathrm{FeS}_{2}\right)$. The deployment of Fe-replete composite is configured on the streamline of the ACC $(\sim 4 \mathrm{~km} / \mathrm{h})$ in order to have a high momentum flux for efficient dispersion of Fe-replete composite on the ocean surface where diatom, copepods, krill and humpback whale stay together $(\sim 100 \mathrm{~m})$. Humpback whales are proposed as a biomarker for the successful iron fertilization on a large-scale since humpback whales feed on krill, which feed on cockpods and diatoms. The fast sinking rate of diatom (0.96 $\left.\mathrm{m} \cdot \mathrm{d}^{-1}\right)[27]$ is very attractive for sequestration of $\mathrm{CO}_{2}$.

Since Fe in the aeolian dust was in the size range of $0.3-1 \mu \mathrm{m}$ and summer krill were mainly in the top $100 \mathrm{~m}$ layer [28] where cyanobacterium picoplankton stays for efficient photosynthesis and $\mathrm{N}_{2}$-fixation, it is important to deploy the Fe enriched eco-friendly composite on ocean surfaces. It will be carried in components of Fe-replete fine silt and clay (11\% of the west Australian desert dust, compared to $3.5 \%$ - $6 \%$ of the aeolian dust), water-buoyant floating enhancer such as carbon black $(\sim 0.1 \mu \mathrm{m})$, rice husk ash containing $90 \%-98 \%$ silica for enhancement of diatom growth, biodegradable plastic foamed poly lactic acid, fine wood chip from sawmills $(<\sim 1400 \mu \mathrm{m})$ and iron-reducing marine bacterium Shewanella algae. This causes the reduction of ferric iron $\left(\mathrm{Fe}^{3+}\right)$ to ferrous iron $\left(\mathrm{Fe}^{2+}\right)$ for facilitated assimilation to picoplankton. Since the wood chips are far greater than other components and their density is less than that of water, the wood chips may play a role of floating moiety whose surface is covered with iron oxides $(0.05-0.1 \mu \mathrm{m})$ from clay particles and reinforced carbon black $(\sim 0.1 \mu \mathrm{m})$ and Chewanella algae $\left(\sim 1.5 \times 10^{7} \mathrm{CFU}\right.$, colony-forming unit) with $100 \%$ survival in cold seawater $\left(2^{\circ} \mathrm{C}\right)$ over a period of 1 to 2 months [29].

The extracellular carbohydrate polymers from five desert soil algae with different cohesion were studied [30] in the stabilization of fine sand grain in the sequence of the great kinematic viscosity of Desmococcus olivaceus (1.1474), Scytonema javanicum (1.0278), Nostoc sp. (1.0149), Phormidium tenue (0.967), and Microcoleus vaginatus (0.9434), which all belong to cyanobacteria except Desmococcus olivaceus. Among them, Scytonema javanicum and Nostoc sp. are $\mathrm{N}_{2}$-fixing marine cyanobacteria. To minimize the occurrence of $\mathrm{FeS}_{2}$ in the ocean, the best strategy is for Fe-replete eco-friendly composite to be floated on the surface of the ocean as long as possible until its finely pulverized Fe component is assimilated by the algae for their growth. Therefore, such two $\mathrm{N}_{2}$-fixing desert soil algae can be used not only as the Fe-replete eco-friendly binder but 
also as a buoyancy promoter due to its copious viscous mucilage. Besides, agar gel for bacterial culture may spherically encapsulate such a Fe-replete composite for buoyancy to be efficiently fed on by phytoplankton in the seawater.

Special precautions may be followed in the preparation of Fe enriched composite, not to violate the United Nations Convention on Biological Diversity (CBD) and the London Convention on the dumping of wastes at sea, as happened near the islands of Haida Gwaii in 2012. For the appropriate iron fertilization, the deployment of Fe replete composite cannot be in the common mode of $\mathrm{FeSO}_{4}$ bubbled with $\mathrm{SF}_{6}$ tracer, but in the mode of eco-friendly composite over the surface water of the fast flow rate ( 4 km per hour) of the ACC.

The location of a few fertilizing ships must be perpendicular to the ACC streamline for wide even distribution on the surface water, not in patch length scale, but in large scale ( $\gg 10 \mathrm{~km}$ ) as suggested by Boyd et al. [31]. Since it took one week for diatom blooms [32] and the flow rate of the ACC is $4 \mathrm{~km} / \mathrm{h}$, the distance between the iron deploying ship and blooms monitoring ship can be at most $672 \mathrm{~km}(=7$ days $\times 24 \mathrm{hrs} \times 4 \mathrm{~km} / \mathrm{h})$ for one week of diatom growth. However, the ACC is analogous to the moving boundary, so the monitoring ship can be behind the iron deploying ship, as close as 10 to $100 \mathrm{~km}$ in the case of the Southern Ocean.

The most preferable location is Shag Rocks $\left(42^{\circ} \mathrm{W}\right)(200 \times 50 \mathrm{~km})$ in South Georgia due to the following reasons; 1 ) located outside of major tectonic plate and micro plate boundaries [33], 2) located where the high nutrient (22.2 - 28.8 $\mu \mathrm{m}$ nitrate) and high chlorophyll $\left(0.46-0.93 \mu \mathrm{g} \cdot \mathrm{L}^{-1}\right)$ are present [34] while the ACC dominated by diatoms cross flows with the Weddell Deep Water dominated by coccolithophorids and silicoflagellates. The iron deployment can be continued for several years to observe the iron stimulated productivity by satellite for chlorophyll and DMS.

There will be on-line monitoring of the algal removal rates of nitrate, phosphate and silicate by corresponding sensors. The algal production rates of dissolved oxygen (DO) in the ocean and the oxygen in the atmosphere will be measured by $\mathrm{DO}$ and $\mathrm{O}_{2}$ sensors. The algal consumption rates of dissolved carbon dioxide $\left(\mathrm{DCO}_{2}\right)$ in the ocean or the fugacity of $\mathrm{CO}_{2}$ in the atmosphere will be recorded by $\mathrm{CO}_{2}$ sensors and the production rate of chlorophyll will be monitored by a chlorophyll sensor system. All of this can be continuously measured on fertilizing ships to see the effect of the iron fertilization. The light-dependent reaction of photosynthesis requires inorganic phosphate to convert $\mathrm{H}_{2} \mathrm{O}$ to $\mathrm{O}_{2}$, which leads to the increase of dissolved oxygen (DO) and thus the uptake rate of the phosphate and iron are also increased during the daytime for ATP production. Therefore, the iron deployment will be made during the daytime. The rate determining step for nitrogen uptake at the Fe-replete condition is the transformation from the nitrite $\left(\mathrm{NO}_{2}^{-}\right)$to the ammonium $\left(\mathrm{NH}_{4}^{+}\right)$with electron transfer of ferredoxin [11]. Since the nitrate reductase prefers anaerobic conditions, the nitrogen uptake mainly occurs during the nighttime, corresponding with the diel 
variation of Synechococcus spp. of maximal cell concentration at midnight [35]. It is thus expected that Synechococcus grows during the night. However, diatoms are capable of dividing at any point of the diel cycle [36]. Therefore, the monitoring of chlorophyll, nitrate phosphate and silicate concentrations after deploying the Fe-replete complex can be made throughout the day and the night for the accurate prediction of algal blooms.

A successful iron fertilization experiment with a deployment period of at least several years can be expected with increased rates of chlorophyll, DMS, DO, $\mathrm{O}_{2}$, $\mathrm{pCO}_{2}$, fugacity of atmospheric $\mathrm{CO}_{2}$ concentrations along with the decreased rates of nitrate, phosphate, silicate concentrations. Dominant plankton feeds in the sequence of picoplankton, diatoms, copepods and krill resulting in the return of humpback whale. Humpback whales live at the surface of the ocean, both in the open ocean and shallow coastline water. In order to be successful in iron fertilization, the appropriate location can be shallow coastline water with abundant numbers of krill and copepods, the latter feeding on ciliates and heterotrophic flagellates eating phytoplankton. Since HNLC regions are rich in nitrate, phosphate and silicate but starved of iron, the iron fertilization is expected to increase the phytoplankton productivity starting from picoplankton, copepods and krill. This may induce, the possible biomarker humpback whales to return to the vicinity of the forgotten whale station of Grytviken in South Georgia. This will prove the success of the iron fertilization, which can be cross-checked by satellite images of nitrate, chlorophyll and DMS (dimethyl sulfide) along with the on-line database established by chlorophyll sensors.

The present method is significantly different from other known methods

1) The present method proposes that sulfur compounds have to be free from iron fertilization, which has never been attempted before.

2) The previous 14 methods of iron fertilizations using $\mathrm{FeSO}_{4} \cdot 7 \mathrm{H}_{2} \mathrm{O}$ as iron additives removed the iron $(\mathrm{Fe})$ in the form of black iron sulfides $\left(\mathrm{FeS} / \mathrm{FeS}_{2}\right)$ (Figure 3(a)) after chemical reaction with sulfur compounds as illustrated in Figure 6. Therefore, algal growth is retarded for Fe-limited conditions at locations with volcanic eruptions.

3) The present method uses the natural clay or desert dust for iron fertilization rather than the previous methods of dumping the chemicals of $\mathrm{FeSO}_{4} \cdot 7 \mathrm{H}_{2} \mathrm{O}$, which is now prohibited by The 2006 London Convention on the Prevention of Marine Pollution by Dumping of Wastes and Other Matter.

4) The present method proposes the appropriate locations for large-scale iron fertilization as Shag Rocks in South Georgia and the Bransfield Strait in the Drake Passage in the Southern Ocean, where no one has never attempted iron fertilization, due to their high momentum flux causing efficient iron deployment.

\section{Conclusions}

The appropriate location for the large-scale sequestration of atmospheric $\mathrm{CO}_{2}$ can be found if the iron fertilization is carried out not only close to deserts but 
also as far from volcanoes, earthquakes and the boundaries of tectonic plates. The appropriate locations for the large-scale iron fertilization are proposed as Shag Rocks and Bransfield Strait in the Southern Ocean due to their high momentum fluxes which are suitable for efficient iron deployment.

Fe-replete compounds are deployed in the ocean to stay as long as possible within a surface depth of $100 \mathrm{~m}$ with the aid of Fe-replete eco-friendly composite with iron-reducing marine bacterium Shewanella algae, Chewanella, algale to avoid the chemical conversion of iron to iron sulfide and enhance phytoplankton digestion. The iron input for algal blooms is not direct iron or iron sulfate. It is preferable to deploy natural clays or soils available on nearby islands, as observed in the Continents and Tasmanian dust, along with volcanic ash desulfurized by rainfall and weathering for long time. Such a Fe-replete complex is encapsulated by agar so that phytoplankton can digest easily and slowly prior to its sinking to the deep ocean where iron is changed to iron sulfide (FeS) and eventually pyrites $\left(\mathrm{FeS}_{2}\right)$.

Since $\mathrm{Fe}$ in the aeolian dust was in the size range of $0.3-1 \mu \mathrm{m}$ and summer krill was mainly in the top $100 \mathrm{~m}$ layer, where cyanobacterium picoplankton stays for efficient photosynthesis and $\mathrm{N}_{2}$-fixation, it is important to deploy the Fe enriched eco-friendly composite on ocean surfaces. It will be carried in components of Fe-replete fine silt and clay (11\% of the west Australian desert dust, compared to $3.5 \%-6 \%$ of the aeolian dust), water-buoyant floating enhancer such as carbon black $(\sim 0.1 \mu \mathrm{m})$, rice husk ash containing $90 \%-98 \%$ silica for enhancement of diatom growth, biodegradable plastic foamed poly lactic acid and fine wood chip from sawmills $(<\sim 1400 \mu \mathrm{m})$ and iron-reducing marine bacterium Shewanella algae to reduce ferric iron $\left(\mathrm{Fe}^{3+}\right)$ to ferrous iron $\left(\mathrm{Fe}^{2+}\right)$ for facilitated assimilation to picoplankton. Since the wood chips are far lighter and/or more buoyant than other components and their density is less than that of water, the wood chips may play a role of floating moiety whose surface is covered with iron oxides $(0.05-0.1 \mu \mathrm{m})$ from clay particles and reinforced carbon black $(\sim 0.1$ $\mu \mathrm{m})$ and Chewanella algae $\left(1.5 \times 10^{7} \mathrm{CFU}\right.$, colony-forming unit) with $100 \%$ survival in cold seawater $\left(2^{\circ} \mathrm{C}\right)$ over a period of 1 to 2 months. Scytonema javanicum and Nostoc $s p$. are $\mathrm{N}_{2}$-fixing marine cyanobacteria. To minimize the occurrence of $\mathrm{FeS}_{2}$ in the ocean, the best strategy is for Fe-replete eco-friendly composite to be floated on the surface of the ocean until its finely pulverized $\mathrm{Fe}$ component is assimilated by the algae for their growth. Therefore, such two $\mathrm{N}_{2}$-fixing desert soil algae can be used not only as the Fe-replete eco-friendly binder but also as a buoyancy promoter due to its copious viscous mucilage. Besides, agar from agar gel for bacterial growth may spherically encapsulate such a Fe-replete composite for buoyancy to be efficiently fed on by phytoplankton in the seawater.

Oceans are categorized by 4 groups such as 2 LC (HNLC, LNLC) and 2 HC (HNHC, LNHC) regions on the basis of the relative degree of accumulation rates for iron from deserts and for sulfur from volcanoes. HNLC regions have a 
stronger lock of sulfur compounds by hydrogen sulfide available from volcanic eruptions without the key of iron sulfides than that of non-HNLC regions. The deployment of Fe-replete composite with a duration of at least several years for successful iron fertilization, is on the streamline of the ACC $(\sim 4 \mathrm{~km} / \mathrm{h})$ in order to have a high momentum flux for efficient dispersion of Fe-replete composite on the ocean surface where diatom, copepods, krill and humpback whales stay together $(\sim 100 \mathrm{~m})$. Humpback whales act as a biomarker for the successful iron fertilization in large-scale since humpback whales which feed on krill, which in turn feed on cockpods and diatoms. The success of the large-scale iron fertilization may be indicated by the return of the humpback whales if there were no humpback whales for a long period before the iron fertilization.

On-line monitoring for the successful iron fertilization is shown by the simultaneous changes of two groups; the increasing concentration group (chlorophyll, $\mathrm{O}_{2}$, DO, DMS) and the decreasing concentration group (nitrate, phosphate, silicate, $\mathrm{CO}_{2}, \mathrm{DCO}_{2}$ ). On-line monitoring of components is carried out on the fertilizing ships; one ship deploying the Fe-replete composite is located at the upward stream of the ACC while another ship monitoring the response of the iron fertilization by both of satellite (chlorophyll-a, nitrate, dimethyl sulfide) and serial sensors (chlorophyll-a, phosphate, silicate, iron, $\mathrm{O}_{2}, \mathrm{DO}, \mathrm{CO}_{2}, \mathrm{DCO}_{2}$ ) are positioned at the downward stream of the ACC. The maximal distance between the two ships can be $672 \mathrm{~km}$ (=7 days $\times 24 \mathrm{hrs} \times 4 \mathrm{~km} / \mathrm{h}$ of the ACC flow rate), considering the growth period of 1 week in diatoms. However, the ACC is analogous to the moving boundary, the monitoring ship can be behind the iron deploying ship at a distance of 10 to $100 \mathrm{~km}$. The monitoring of chlorophyll-a, nitrate phosphate, and silicate concentrations after deployment of the Fe-replete complex is made throughout the day and night for the accurate prediction of algal blooms.

\section{Acknowledgements}

This work was funded by The University of Suwon and G-Land, Republic of Korea. Editing work undertaken by Professor Jonathan Wright is also greatly appreciated. Typing work by Mr. Kyung-Hoon Min is also appreciated.

\section{Conflicts of Interest}

The author declares no conflicts of interest regarding the publication of this paper.

\section{References}

[1] Kim, T.J. (2020) Transmission and Prevention of Wuhan Coronavirus Disease 2019 (COVID-19) during Minimum Sunspot Number. Global Journal of Medical Research: F Disease, 20, 13-33. https://doi.org/10.34257/GJMRFVOL20IS3PG13

[2] Martin, J.H. and Fitzwater, S.E. (1988) Iron Deficiency Limits Phytoplankton Growth in the North-East Pacific Subarctic. Nature, 331, 341-343.

https://doi.org/10.1038/331341a0 
[3] Minas, H.J., Minas, M. and Packard, T.T. (1986) Productivity in Upwelling Areas Deduced from Hydrographic and Chemical Fields. Limnology and Oceanography, 31, 1182-1206. https://doi.org/10.4319/lo.1986.31.6.1182

[4] Martin, J.H., et al. (1994) Testing Iron Hypothesis in Ecosystems of the Equatorial Pacific Ocean. Nature, 371, 123-129. https://doi.org/10.1038/371123a0

[5] Kim, T.J., Hong, G.H., Kim, D.G. and Baskaran, M. (2019) Iron Fertilization with Enhanced Phytoplankton Productivity under Minimal Sulfur Compounds and Grazing Control Analysis in HNLC Region. American Journal of Climate Change, 8, 14-39. https://doi.org/10.4236/ajcc.2019.81002

[6] Boyd, P.W., et al. (2005) FeCycle: Attempting an Iron Biogeochemical Budget from a Mesoscale. Global Biogeochemical Cycles, 19, GB4S20.

https://doi.org/10.1029/2005GB002494

[7] Korehi, H., Blöthe, M., Sitnikova, M.A., Dold, B. and Schippers, A. (2013) Metal Mobilization by Iron- and Sulfur-Oxidizing Bacteria in a Multiple Extreme Mine Tailings in the Atacama Desert, Chile. Environmental Science \& Technology, 47, 2189-2196. https://doi.org/10.1021/es304056n

[8] Mahowald, N.M., et al. (2005) Atmospheric Global Dust Cycle and Iron Inputs to the Ocean. Global Biogeochemical Cycles, 19, 4.

https://doi.org/10.1029/2004GB002402

[9] Maher, B.A., Prospero, J.M., Mackie, D., Gaiero, D., Hesse, P.P. and Balkanski, Y. (2010) Global Connections between Aeolian Dust, Climate and Ocean Biogeochemistry at the Present Day and at the Last Glacial Maximum. Earth-Science Reviews, 99, 61-97. https://doi.org/10.1016/j.earscirev.2009.12.001

[10] Law, C.S. and Boyd, P.W. (2001) The Fate of Added Iron during a Mesoscale Fertilization Experiment in the Southern Ocean. Deep Sea Research, II, 48, 2703-2743. https://doi.org/10.1016/S0967-0645(01)00015-7

[11] Walsh, J.J. and Steidinger, K.A. (2001) Saharan Dust and Florida Red Tides: The Cyanophyte Connection. Journal of Geophysical Research, 106, 11,597-11,612. https://doi.org/10.1029/1999JC000123

[12] Aquilina, A., Homoky, W., Hawkes, J.A. and Lyons, T.W. (2014) Hydrothermal Sediments Are a Source of Water Column Fe and Mn in the Bransfield Strait, Antarctica. Geochimica et Cosmochimica Acta, 137, 64-80. https://doi.org/10.1016/j.gca.2014.04.003

[13] Duggen, S., Olgun, N., Croot, P., Hoffmann, L., Dietze, H., Delmell, P. and Teschner, C. (2010) The Role of Airborne Volcanic Ash for the Surface Ocean Biogeochemical Iron-Cycle: A Review. Biogeosciences, 7, 827-844.

https://doi.org/10.5194/bg-7-827-2010

[14] Schrope, M. (2008) Oceanography: Red Tide Rising, Nature News, 452, 24-26. https://doi.org/10.1038/452024a

[15] Langmann, B. (2014) On the Role of Climate Forcing by Volcanic Sulphate and Volcanic Ash. Advances in Meteorology, 2014, Article ID: 340123. https://doi.org/10.1155/2014/340123

[16] Mcanena, A. (2011) The Reactivity and Isotopic Fractionation of Fe-Bearing Minerals during Sulfidation: An Experimental Approach. PhD Thesis, Newcastle University, Newcastle upon Tyne.

[17] Dixon, D., Mayewski, P.A., Kaspari, S., Kreutz, K.J. and Hamilton, G.S. (2005) A 200 Year Sulfate Record from 16 Antarctic Ice Cores and Associations with Southern Ocean Sea-Ice Exten. Annals of Glaciology, 41, 155-166. https://doi.org/10.3189/172756405781813366 
[18] Karl, K. (1968) Turekian: Oceans. Prentice-Hall, Upper Saddle River.

[19] Tan, S.C., Yao, X., Gao, H.W., Shi, G.Y. and Yue, X. (2013) Variability in the Correlation between Asian Dust Storms and Chlorophyll-a Concentration from the North to Equatorial Pacific. PLoS ONE, 8, e57656. https://doi.org/10.1371/journal.pone.0057656

[20] Lin, I.-I., Hu, C., Li, Y.H., Ho, T.Y., Fischer, T.P., Wong, G.T.F., Wu, J., Huang, C.W., Chu, D.A., Ko, D.S. and Chen, J.P. (2011) Fertilization Potential of Volcanic Dust in the Low-Nutrient Low-Chlorophyll Western North Pacific Subtropical Gyre: Satellite Evidence and Laboratory Study. Global Biogeochemical Cycles, 25, GB1006. https://doi.org/10.1029/2009GB003758

[21] Dugdale, R.C., Wilkerson, F.P. and Minas, H.J. (1995) The Role of a Silicate Pump in Driving New Production. Deep Sea Research, 42, 697-719. https://doi.org/10.1016/0967-0637(95)00015-X

[22] Atkinson, A., Ward, P., Hill, A., Brierley, A.S. and Cripps, G.C. (1999) Krill-Copepod Interactions at South Georgia, Antarctica, II. Euphausia superba as a Major Control on Copepod Abundance. Marine Ecology Progress Series, 176, 63-79.

https://doi.org/10.3354/meps176063

[23] Strzepek, R. (2018) Control of Diatom Bloom Dynamics in the Open Ocean. http://www.academia.edu/2018923/Microbial

[24] Ebersbach, F., Assmy, P., Martin, P., Schulz, I., Wolzenburg, S. and Nothig, E.M. (2014) Particle Flux Characterization and Sedimentation Patterns of Protistan Plankton during the Iron Fertilization Experiment LOHAFEX in the Southern Ocean. Deep-Sea Research Part I, 89, 94-103. https://doi.org/10.1016/j.dsr.2014.04.007

[25] Hamme, R.C., et al. (2010) Volcanic Ash Fuels Anomalous Plankton Bloom in Subarctic Northeast Pacific. Geophysical Research Letters, 37, L19604. https://doi.org/10.1029/2010GL044629

[26] Shaked, Y. and Lis, H. (2012) Disassembling Iron Availability to Phytoplankton. Frontiers in Microbiology, 3, 123. https://doi.org/10.3389/fmicb.2012.00123

[27] Bienfang, P.K. and Harrison, P.J. (1984) Sinking Rate Response of Natural Assemblages of Temperate and Subtropical Phytoplankton to Nutrient Depletion. Marine Biology, 83, 293-300. https://doi.org/10.1007/BF00397462

[28] Sverdrup, H. (1953) On Conditions for the Vernal Blooming of Phytoplankton. ICES Journal of Marine Science, 18, 287-295. https://doi.org/10.1093/icesjms/18.3.287

[29] Gram, L., Bundvard, A., Melchiorsen, J., Johansen, C. and Fonnesbech, V.B. (1999) Occurrence Shewanella algae in Danish Coastal Water and Effects of Water Temperature. Applied and Environmental Microbiology, 65, 3896-3900. https://doi.org/10.1128/AEM.65.9.3896-3900.1999

[30] Hu, C., Liu, Y., Paulsen, B.S., Petersen, D. and Klaveness, D. (2003) Extracellular Carbohydrate Polymers from Five Desert Soil Algae with Different Cohesion in the Stabilization of Fine Sand Grain. Carbohydrate Polymers, 54, 33-42. https://doi.org/10.1016/S0144-8617(03)00135-8

[31] Boyd, P.W., et al. (2007) Mesoscale Iron Enrichment Experiments 1993-2005: Synthesis and Future Directions. Science, 15, 612-617.

https://doi.org/10.1126/science.1131669

[32] Barber, R.T. and Hiscock, M.R. (2006) A Rising Tide Lifts All Phytoplankton: Growth Response of Other Phytoplankton Taxa in Diatom-Dominated Blooms. Global Biogeochemical Cycles, 20, GB4S03. https://doi.org/10.1029/2006GB002726 
[33] Barker, P.F. (2001) Scotia Sea Regional Tectonic Evolution: Implications for Mantle Flow and Palaeocirculation. Earth-Science Review, 55, 1-39. https://doi.org/10.1016/S0012-8252(01)00055-1

[34] Koike, I., Holm-Hansen, O. and Biggs, D.C. (1986) Inorganic Nitrogen Metabolism by Antarctic Phytoplankton with Special Reference to Ammonium Cycling. Marine Ecology_Progress Series, 30, 105-116. https://doi.org/10.3354/meps030105

[35] Tsai, A.Y., Gong, G., Sanders, R.W. and Chiang, K.P. (2012) Viral Lysis and Nanoflagellate Grazing as Factors Controlling Diel Variations of Synechococcus spp. Summer Abundance in Coastal Waters of Taiwan. Aquatic Microbial Ecology, 66, 159-167. https://doi.org/10.3354/ame01566

[36] Yool, A. and Tyrrell, T. (2003) Role of Diatoms in Regulating the Ocean's Silicon Cycle. Global Biogeochemical Cycles, 17, 1103. 